\title{
The Permanent Establishment Concept In Double Tax Agreements Between Developed And Developing Countries: Canada/South Africa As A Case In Point
}

\author{
Lee-Ann Steenkamp, University of the Western Cape, South Africa
}

\begin{abstract}
In this era of globalisation, developing countries have resorted to double tax agreements in order to attract foreign direct investment. The extent to which a country's tax treaty policy favours developing countries or not depends upon the extent to which the country is prepared to adopt provisions from the UN model tax convention as opposed to the OECD model. Developing countries in particular should carefully consider the design of their tax treaties so as to effectively combat tax avoidance, without sacrificing foreign direct investment. To this end, the Canada/South Africa tax treaty is compared and contrasted with these two models. The concept of permanent establishment is reviewed in this context. It was found that the Canada/South Africa tax treaty is overwhelmingly based on the OECD model. This could indicate that South Africa has a deliberate tax treaty policy of ceding taxing rights to other countries. Thus, developing countries are seemingly unable or unwilling to make use of the UN model so as to retain greater source taxation. A number of recommendations are made to broaden the scope for the source taxation of business income in the developing country.
\end{abstract}

Keywords: Double Tax Agreement; Foreign Direct Investment; Organisation for Economic Cooperation and Development; OECD; Permanent Establishment; Place of Effective Management; Residence; South Africa; Source; Tax Treaty; United Nations

\section{INTRODUCTION}

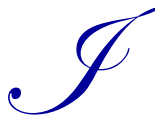

n this era of globalisation, the increased mobility in capital (as opposed to labour) has led to tax competition, in which sovereign countries lower their tax rates on income earned by foreigners within their borders in order to attract both portfolio and direct investment (Avi-Yonah, 2001, p. 60). In their aim to increase foreign direct investment inflows, developing countries have resorted to double tax agreements to signal their commitment to stable, correct, and often favourable treatment of foreign investors (Neumayer, 2007, p. 1503).

The Organisation for Economic Cooperation and Development (OECD) notes that to encourage crossborder trade there must be certainty and stability in two key areas: permanent establishments and transfer pricing' (OECD, 2011, p. 60). By signing tax treaties, developing countries provide foreign investors with security and stability as regards the issue of taxation in addition to the relief from double taxation (Neumayer, 2007, p. 1503).

The main use of the concept of a permanent establishment is to determine the right of a Contracting State to tax the profits of an enterprise of the other Contracting State (OECD, 2010, p. 92). Consequently, implementing an appropriate tax policy is crucial, as the revenue that developing countries are able to raise from the income earned in their countries on cross-border trade and investment flows is often significant and critical for the development of their economy and for raising the standard of living of their impoverished residents (Brooks, 2009, p. 2). 


\section{RESEARCH OBJECTIVE, METHOD, AND SCOPE}

The objective of this paper is to compare and contrast the tax treaty policy in respect of the permanent establishment provisions embodied in the Canada/RSA tax treaty (South Africa, 1997) with the model tax conventions developed by the OECD and the United Nations (UN). ${ }^{1}$

The research is a descriptive study and entails a literature review of and reference to statutory law, tax treaties, and published articles and textbooks. This comparative study is of an exploratory nature and serves to establish a baseline for the subsequent examination of South Africa's evolving tax treaty policy towards (a) developed countries, (b) developing countries, and (c) African countries in particular. ${ }^{2}$ An analysis of tax treaty design is a telling indicator of a country's public policy; as such, this paper seeks to contribute to an understanding of a developing country's policies regarding attracting foreign investors without sacrificing vital tax revenue. ${ }^{3}$ This paper builds on previous research conducted and aims to offer arguments as to how a government could reconsider its tax treaty policy. ${ }^{4}$ This comparative exercise will assist in determining the extent to which the treaty expands (or not) the scope for the source taxation of business income.

The notion of a permanent establishment integrates a number of attributes, chief amongst which are:

- $\quad$ The period required for building, construction or an assembly project;

- $\quad$ Services;

- $\quad$ Exclusions from the definition of permanent establishment;

- $\quad$ Dependent agents;

- $\quad$ Insurance activities;

- $\quad$ Profit allocation to permanent establishments; and

- The taxation of the alienation of property.

For each of the attributes listed above, the paper firstly provides a theoretical foundation and thereafter a comparison of the OECD model, UN model, and Canada's existing treaties. The Canada/RSA treaty is then weighed against this comparison, in order to ascertain to which model it adheres to as well as to draw inferences from Canada's treaty policy.

It is acknowledged that although the policy of tax treaties is multi-faceted and complex, this paper takes only one concept (viz. permanent establishment) and examines it in some detail. Future research could include a replication of Brooks' (2009) study from a South African point of view as well as incorporating other treaty concepts (e.g., beneficial ownership or anti-avoidance articles). ${ }^{5}$ Consequently, the scope of this paper is limited to an examination of the permanent establish concept, as negotiated in the Canada/RSA tax treaty.

An earlier paper contains an exposition of the rationale for comparing Canada and South Africa, as well as a concise background to the OECD and UN models. ${ }^{6}$ Accordingly, it is considered beyond the scope of this paper to again elaborate on these matters. At this stage, it is apposite to state that due to Canada's classification as a

\footnotetext{
${ }^{1}$ The OECD Model Tax convention on Income and Capital ('OECD model') was prepared by developed countries in 1963. The UN Model Double Taxation Convention between Developed and Developing Countries ('UN model') came into being under the auspices of the UN in 1980, in an attempt to reflect the interests of developing countries.

${ }^{2}$ According to the latest information on the South African Revenue Service (SARS) website, South Africa has a total of 73 tax treaties in force (some of which have been amended by protocols). Of this number, 21 is with African countries and 52 with the rest of the world. See http://www.sars.gov.za/Legal/International-Treaties-Agreements/DTA-Protocols/Pages/DTAs-and-Protocols-(Rest-of-the-World).aspx

${ }^{3}$ Indeed, Brooks $(2009$, p. 1) likens the importance of studying the design of tax treaties to that of substantive tax law: it reveals the balance of interest group power in a country, the prevailing ideas, the ambitions of its politicians, and the institutions of government.

${ }^{4}$ In addition to Brooks (2009), also see, amongst others, Mazansky (2009), West (2009) and Elliffe (2011).

${ }^{5}$ Thanks is extended to the anonymous reviewer for valuable comments made on an earlier version of this paper. This includes, amongst others, a suggestion to extend the scope of the research to, for example, interviewing specialists who could provide more insight on the research findings of this literature study. It is envisaged that such an empirical study could also be extended to incorporate the findings of the other areas for future research as mentioned above.

${ }^{6}$ Refer to Steenkamp (2013).
} 
developed country, its extensive history of exchanging information for tax purposes and having one of the largest tax treaty networks, Canada was selected as a proxy for developed countries.

Furthermore, the same comparative, descriptive research method of the previous paper is adopted in this paper. Brooks' (2009) study is used as a basis for comparative analysis in this paper. For the sake of clarity, his research approach is reproduced here: Brooks conducted an extensive research project during 2008, analysing the 53 tax treaties that Canada has entered into between 1988 and June 2008. As the Canada/RSA tax treaty was signed into force in May 1997, this treaty was automatically included in Brooks' analysis. In the period June 2008 to 31 December 2012, Canada has entered into three additional treaties with Colombia, Greece, and Turkey. Accordingly, this paper has incorporated these three treaties into the research findings of Brooks' analysis. Henceforth, all references to treaties in Brooks' study will also include Colombia, Greece, and Turkey.

Since treaties apply only between persons who are residents of one or both of the Contracting States, the next paragraph will examine the interpretation of the concept of 'tax residence.'

\section{TAX RESIDENCE}

For the purposes of the OECD model, the term 'resident of a Contracting State' means any person who, under the laws of that state, is liable to tax therein by reason of his domicile, residence, place of management, or any other criterion of a similar nature, and also includes that state and any political subdivision or local authority thereof. ${ }^{7}$ The UN model definition for 'resident' is similar, except that it adds 'place of incorporation' as an additional criterion in Art 4(1).

Furthermore, where a person other than an individual is a resident of both Contracting States, both the OECD and UN models then deem it to be a resident only of the state in which its place of effective management is situated. ${ }^{8}$ The word 'only' was later inserted as a tie-breaker rule for determining the residence of dual residents, other than individuals (UN, 2012, p. 94).

According to the OECD model, the place of effective management is the place where key management and commercial decisions that are necessary for the conduct of the entity's business as a whole are made in substance. All relevant facts and circumstances must be examined to determine the place of effective management. An entity may have more than one place of management, but it can have only one place of effective management at any given time (OECD, 2010, p. 88).

The UN model takes the following circumstances into account when establishing the place of effective management: the place where a company is actually managed and controlled, the place where the decision-making at the highest level on the important policies essential for the management of the company takes place, the place that plays a leading part in the management of a company from an economic and functional point of view and the place where the most important accounting books are kept (UN, 2012, p. 94).

Despite its widespread use, the South African Revenue Service (SARS) notes that the term 'place of effective management' has never had a universally accepted meaning (SARS, 2011, p. 5). There is, however, a broad consensus that the term 'place of effective management' has at least two main interpretations, namely the place where the board of directors meets or the place where the senior management operates. In South Africa, SARS' view is set out in Interpretation Note No. 6 (SARS, 2002). ${ }^{9}$ The place of effective management is generally determined as the place where the company is managed on a regular day-to-day basis by the directors or senior managers of the company, irrespective of where the board of directors meet (SARS, 2002, p. 3). ${ }^{10}$

\footnotetext{
${ }^{7}$ Per OECD model Art 4(1). This term, however, does not include any person who is liable to tax in that State in respect only of income from sources in that State or capital situated therein.

${ }^{8}$ Per OECD model Art 4(3) and UN model Art 4(3). The OECD model commentary to Art 4 at 88 explains that the "place of effective management' has been adopted as the preference criterion for persons other than individuals.

${ }^{9}$ To this end, SARS' Discussion Paper (SARS, 2011) provides a framework for discussion of possible revisions to Interpretation Note No. 6. The public was invited to submit commentary by 30 October 2011. Interpretation Note No. 6 has not been revised yet as, presumably, SARS is still working on a new draft version which incorporates commentary received.

${ }^{10} \mathrm{Haupt}$ (2012, p. 29) notes that it is important to distinguish 'effective management' from 'control' and from 'management and control'.
} 
Table 1 compares the 'place of effective management' requirement.

Table 1: Comparison of 'Place of Effective Management' Requirement

\begin{tabular}{|l|l|}
\hline OECD model & $\begin{array}{l}\text { Where the key management and commercial decisions necessary for the conduct of the business as a whole } \\
\text { are made in substance. }\end{array}$ \\
\hline UN model & $\begin{array}{l}\text { Where the company is actually managed and controlled; where the highest level decision-making occurs; } \\
\text { the place from where the company is economically and functionally lead. }\end{array}$ \\
\hline SARS & Where the day-to-day management of the company is conducted by the directors or senior managers. \\
\hline
\end{tabular}

Article 4(1) of the Canada/RSA treaty differentiates between tax resident status in Canada and the RSA as follows:

(a) In the case of Canada:

(i) any person who, under the laws of Canada, is liable to tax in Canada by reason of his domicile, residence, place of management, place of incorporation, or any other criterion of a similar nature;

(ii) Canada or a political subdivision or local authority thereof or any agency or instrumentality of Canada, or subdivision or authority thereof;

(b) In the case of South Africa, any individual who is ordinarily resident in South Africa and any other person which has its place of effective management in South Africa. [own emphasis]

The Canada/RSA treaty thus follows the UN model in so far as the Canadian definition of tax resident is concerned, as it refers to the place of incorporation. The South African definition makes use of the 'ordinarily resident' criterion for an individual, which aligns with the 'by reason of his residence' criterion in both the OECD and UN models. As regards to the tax resident status of non-individuals, the requirement of 'place of effective management' resembles both models.

In order to challenge treaty shopping on the basis of tax residence, these provisions suggest two possible arguments: either that the taxpayer is not liable to tax in the Contracting State by reason of domicile, residence, etc. or that its place of effective management is not situated in the Contracting State from which the treaty benefit is sought (Duff, 2010, p. 6).

Both the OECD and UN models employ the permanent establishment concept to delineate the degree of contact a non-resident enterprise carrying on business in a jurisdiction requires before it is subject to tax there. As such, the remainder of the paper will examine the concept of 'permanent establishment.'

\section{PERMANENT ESTABLISHMENT}

It is a principle of international double tax agreements that the profits of an enterprise of a Contracting State are taxable only in that state, unless the enterprise carries on business in the other Contracting State through a permanent establishment therein (Oguttu, 2009, p. 773). Thus, even if a permanent establishment exists, only the profits attributable to the permanent establishment are taxable. ${ }^{11}$

The OECD model commentary to Art 10(4), Art 12(4), and Art 12(3) state that it is necessary to check whether there really is a permanent establishment in the other country (OECD, 2010, pp. 193, 214, 232). For this purpose, apart from a fixed place of business, the company must carry on a business through a permanent establishment and the shares, loans, property or rights must be effectively connected to the activity of the permanent establishment (Martín Jiménez, 2004, p. 26).

For South African income tax purposes, the term 'permanent establishment' is defined in Section 1 of the Income Tax Act No 58 of 1962, as amended, as a permanent establishment as defined from time to time in Art 5 of the OECD model. The definition of a permanent establishment in Art 5 shows that there must be either a physical presence in the state concerned or there must be a dependent agent (Oguttu, 2006, p. 150).

\footnotetext{
${ }^{11}$ Oguttu (2009) provides a detailed exposition on the criticisms and the challenges of applying these rules from a South African perspective. It is, however, considered beyond the scope of this paper to address the workings of the various OECD profit attribution rules.
} 
Article 5(1) contains a standard definition of a permanent establishment, viz. a fixed place of business through which the business of an enterprise is wholly or partly carried on. Article 5(2) then widens this definition by specifically including:

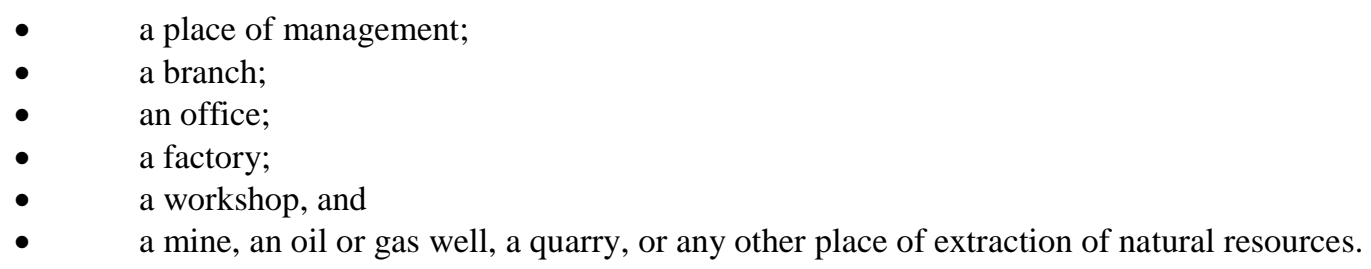

The UN model departs from the OECD model's definition largely by broadening the definition of activities that might be sufficient for an enterprise to be found to have a permanent establishment. These activities will now be briefly addressed.

\section{Period Required for Building, Construction, or Assembly Project}

First, the UN model reduces the amount of time required for a building site or construction or assembly project to exist to be considered a permanent establishment. Engaging in a construction or assembly project in a country would generally be considered to be 'carrying on business' in a country and therefore under many countries' domestic tax systems (including Canada's) the enterprise would be subject to tax (Brooks, 2009, p. 7). According to the OECD model, such a project will be considered to be a permanent establishment only if it exists for more than twelve months. Under the UN model, such a project may be a permanent establishment if it exists for six months.

The wording of Art 5(3)(a) in the Canada/RSA tax treaty is in accordance with the OECD model, by requiring a period of activity of more than twelve months. It was found that Canada agreed to the OECD-prescribed period in seven of the treaties with middle-income countries; the time period was reduced for the other twelve treaties with middle-income countries; as regards treaties with low-income countries, the periods of fourteen were reduced, ranging from a required three to nine months (Brooks, 2009, p. 7). It is clear, then, that Canada is more likely to grant shorter periods in this part of the permanent establishment article if the country is a middle- or lowincome country than it is to deviate from the OECD-suggested period of time for high-income countries (Brooks, 2009, p. 7). Although Canada is more likely to grant a lower time period before a building site, construction, or assembly project may be considered a permanent establishment where the treaty partner is a middle or low-income country, this has not been the case with the South Africa treaty.

\section{Services}

Secondly, prior to the 2011 revisions, the UN model expanded the definition of permanent establishment in Art 5 to include the general furnishing of services, including consultancy services, by an enterprise through employees or other personnel where the activities continue for the same or a connected project within the country for more than six months, or a lesser period, within any twelve-month period. Under the OECD model, such activities alone would not necessarily constitute a permanent establishment. The rationale for this expansion of the permanent establishment concept in the UN model was that such services were analogous to a building site or other construction project activities (UN, 2012, p. 108). The UN model commentary explains that many developing countries believe that management and consultancy services should be covered because the provision of these services in developing countries by enterprises of industrialised countries can generate large profits (UN, 2012, p. 108).

In the 2011 revision of the UN model, a change in the wording of the six-month rule of par 3(b) was agreed to, which was amended to read:

...but only if activities of that nature continue (for the same or a connected project) within a Contracting State for a period or periods aggregating more than 183 days in any twelve-month period commencing or ending in the fiscal year concerned [own emphasis]. 
This was seen as providing greater consistency with the approach taken in Art 14(1)(b).

The Canada/RSA tax treaty follows neither the OECD model (which does not include the general furnishing of services) nor the UN model, as Art 5(3)(b) requires the activities to continue for a period of more than twelve months. The inclusion of the furnishing of services is in accordance with Canada's willingness to include this provision in its tax treaties where the treaty partner is a middle- or low-income country. Canada agreed to add this provision in ten of its treaties with middle-income countries and in twelve of its treaties with low-income countries; generally speaking, the period of time before the services may constitute a permanent establishment ranges from three months to twelve months (Brooks, 2009, p. 8).

\section{List of Exclusions}

Thirdly, the OECD model lists six circumstances in Art 5 par 4(a) in which, despite the enterprise having a fixed place of business, it is not considered a permanent establishment since the activities are preparatory or ancillary in nature. These exclusions are generally designed to remove from the scope of source-based taxation the use of facilities simply for storage or delivery, the maintenance of a stock of goods without more, the maintenance of a fixed place simply for purchasing goods, and the maintenance of a fixed place solely for a preparatory or auxiliary reason. In essence, these exclusions remove casual or temporary business activities from the scope of source-based taxation.

The UN model eliminates the 'delivery of goods' from the first exclusion contained in the OECD model. Under the OECD model, if an enterprise simply uses facilities for the delivery of goods or maintains a stock of goods in that jurisdiction for delivery, that activity alone is not sufficient to constitute a permanent establishment. Under the UN model, the delivery of goods exclusion is not listed as an exception to the permanent establishment definition. The deletion of the word 'delivery' reflects the majority view of the committee that a 'warehouse' used for that purpose should, if the requirements of par 1 are met, be a permanent establishment (UN, 2012, p. 119).

In this instance, Art 5(4)(a) of the Canada/RSA tax treaty is based on the OECD list of exclusions. This is in accordance with Canada's negotiations with middle- or low-income countries. However, Canada has followed the UN model in one treaty with a middle-income country and with six low-income countries; indeed, it has been relatively unusual for Canada to agree to remove the mere delivery of goods or merchandise from the rule that deems such activities not to be a permanent establishment (Brooks, 2009, p. 8).

\section{Dependent Agent}

As an alternative to setting up an office or other fixed place of business, an enterprise may conduct business in a country by sending an agent to act on its behalf. A taxpayer is then deemed to have a permanent establishment in a country if it has a 'dependent agent' in the country that habitually exercises authority to conclude contracts on behalf of the taxpayer (Oguttu, 2009, p. 775). ${ }^{12}$ Whether or not that agent constitutes a permanent establishment depends largely on the degree of independence of the agent.

Under the OECD model, if an enterprise has a dependent agent who is able to habitually exercise the authority to conclude contracts in the name of the enterprise, that agent will constitute a permanent establishment. As a fourth change to the OECD definition of permanent establishment, the UN model extends the concept of a dependent agent.

Under the UN model, a dependent agent is an agent who either (a) concludes contracts on behalf of the developing country enterprise or (b) has no authority to conclude contracts, but who regularly delivers goods or merchandise on behalf of the enterprise. In other words, the UN model expands the definition of permanent establishment by including an agent who habitually maintains in the state a stock of goods or merchandise from which he or she regularly delivers goods or merchandise on behalf of the enterprise. With the addition of par 5(b),

\footnotetext{
${ }^{12}$ The author also explains that a 'dependent agent' is generally one that is subject to the principal's detailed instruction and comprehensive control and normally bears little or no business risk from its own activities, whereas an 'independent agent' is legally and economically autonomous of its principal.
} 
relating to the maintenance of a stock of goods, this paragraph is broader in scope than par 5 of the OECD model. The UN model commentary notes that some countries believe that a narrow formula might encourage an agent who was, in fact, dependent to represent himself as acting on his own behalf (UN, 2012, p. 126).

Again, the Canada/RSA tax treaty in Art 5(5) echoes the wording of the OECD model. For high- and middle-income countries, Canada has been unlikely to include language similar to that suggested by the UN model that widens the circumstances in which a dependent agent will be deemed to be a permanent establishment. Only one tax treaty with a high-income country and three with middle-income countries include this provision; Canada does seem slightly more amenable towards this extension of the concept of permanent establishment with lowincome countries, having agreed to it in six of its 21 tax treaties (Brooks, 2009, p. 9).

\section{Further Dependent Agent Status}

Fifthly, the UN model considers independent agents to be a permanent establishment where their activities are wholly or almost wholly devoted to the enterprise and the conditions for their relationship are different from those that would have been made between independent enterprises.

The UN model commentary to Article 5(7) explains that independent status is less likely if the activities of the agent are performed wholly or almost wholly on behalf of only one enterprise over the lifetime of the business or a long period of time (UN, 2012, p. 130). However, this fact is not in itself determinative. All the facts and circumstances must be taken into account to determine whether the agent's activities constitute an autonomous business conducted by him in which he bears risk and receives reward through the use of his entrepreneurial skills and knowledge.

In the 1980 edition of the UN model, this requirement read as follows:

However, when the activities of such an agent are devoted wholly or almost wholly on behalf of the enterprise, he will not be considered an agent of an independent status within the meaning of this paragraph.

It was subsequently recognised that this sentence had given rise to anomalous situations (UN, 2012, p. 131). The concern was that if the number of enterprises for which an independent agent was working fell to one, the agent would, without further examination, be treated as dependent. The revised version makes clear that the essential criterion for automatically treating an agent as not being of 'an independent status' is the absence of the arm's length relationship. The UN model commentary states that the mere fact that the number of enterprises for which the independent agent acts has fallen to one does not of itself change his status from independent to dependent, though it might serve as an indicator of the absence of the independence of that agent (UN, 2012, p. 131).

It could be contended that the UN model is probably better off without the exclusion, as it could be easily avoided by a company acting as an agent for a number of related companies, rather than as an agent for one company in a corporate group (Vann, 2011, p. 8). ${ }^{13}$ This provision is not present in the OECD model, nor is it contained in the Canada/RSA tax treaty. Canada has included this provision in two of its tax treaties with highincome countries, in eight of its tax treaties with middle-income countries and in six of its tax treaties with lowincome countries (Brooks, 2009, p. 9). Accordingly, the Canada/RSA tax treaty is based on the OECD model in this respect.

\section{Insurance Activities}

The UN model expands the definition of permanent establishment to include insurance activities that would not constitute a permanent establishment under the OECD model. Under the OECD model, insurance premiums are only taxable in the source country if the insurance enterprise has an agent authorised to conclude contracts on its behalf (OECD, 2010, p. 108). According to the definition of the term 'permanent establishment', an insurance

\footnotetext{
${ }^{13}$ The author does, however, concede that the UN model is not much harmed by this exclusion. Regardless, it will be very difficult for an agent to establish independence if it acts mainly (which may fall short of 'almost wholly') for related parties.
} 
company of one state may be taxed in the other state on its insurance business, if it has a fixed place of business within the meaning of par 1 or if it carries on business through a person within the meaning of par 5. Since agencies of foreign insurance companies sometimes do not meet either of the above requirements, it is conceivable that these companies do large-scale business in a state without being taxed in that state on their profits arising from such business.

Broadening the definition of permanent establishment, the UN model provides that if an insurance company collects premiums in a country or insures risks in the country through an employee or dependent agent in the country, then the insurance company has a permanent establishment in that jurisdiction, and the permanent establishment may be subject to tax (UN, 2012, p. 127). The UN model commentary states that par 6 is necessary because insurance agents generally have no authority to conclude contracts; thus, the conditions of par 5(a) would not be fulfilled (UN, 2012, p. 127). If an insurance agent is independent, however, the profits of the insurance company attributable to his or her activities are not taxable in the source state as the provisions of Art 5(7) would be fulfilled and the enterprise would not be deemed to have a permanent establishment.

The Canada/RSA tax treaty contains no such provision and therefore reflects the OECD model's approach. This appears to reflect Canada's general stance on provisions of insurance activities in treaties; Canada has included this provision in two tax treaties with a high-income country, five with middle-income countries and in seven treaties with low-income countries (Brooks, 2009, p. 9).

\section{Expanding the Profit Allocated to Entities with a Permanent Establishment}

In addition to defining the concept of permanent establishment, the OECD model provides the basis on which the activities associated with a permanent establishment will be subject to tax. Generally speaking, the OECD model suggests that an enterprise should only be taxable in the source jurisdiction on the profits it earns that relate to its permanent establishment and those profits should be calculated in the same way they would be for domestic business activities - income tax should be applied to the permanent establishment's net profits. In terms of calculating the profits to be subject to tax, the UN model makes two significant suggested changes.

\section{Force of Attraction Principle}

First, the UN model suggests a modification that more closely aligns the calculation of the permanent establishment's taxable income with the 'force of attraction' principle - in other words, once an enterprise has a permanent establishment in a jurisdiction, all income derived by the enterprise in the jurisdiction should be subject to tax there.

Under Art 7(1) of the UN model, in addition to profits of the permanent establishment that are calculated as per the OECD model, the profits of the permanent establishment will include profits that are attributable to:

- $\quad$ sales of goods or merchandise of the same or similar kind as those sold through the permanent establishment; and

- other business activities carried on of the same or similar kind as those carried on through that permanent establishment.

These two additional clauses mean that the UN model amplifies the corresponding article in the OECD model by including a limited force of attraction rule. This allows the country in which the permanent establishment is located to tax not only the profits attributable to that permanent establishment, but other profits of the enterprise derived in that country to the extent allowed under the article (UN, 2012, p. 142). ${ }^{14}$

The wording of Art 7(1) in the Canada/RSA tax treaty is in accordance with the OECD model. In recent years, Canada seems to have become less likely to grant the UN model expansion, having agreed to the provision in

\footnotetext{
${ }^{14}$ The UN model commentary noted that the force of attraction rule is limited to business profits covered by Art 7 and does not extend to income from capital (dividends, interest, and royalties) covered by other treaty provisions.
} 
only two treaties since 1996; two of Canada's tax treaties with middle-income countries and six of Canada's tax treaties with low-income countries have included this expansion to the taxing jurisdiction of the source country (Brooks, 2009, p. 10).

\section{Head Office Expenses}

Secondly, both the OECD and the UN models allow, in general, for the deduction from business profits of head office expenses incurred for the purpose of the business of the permanent establishment. This includes executive and general administrative expenses, even if they are incurred in the non-source state. ${ }^{15}$ The OECD model commentary to Art 7(3) clarifies, in relation to the expenses of a permanent establishment, the general directive laid down in par 2. The paragraph specifically recognises that in calculating the profits of a permanent establishment, allowance is to be made for expenses, wherever incurred, that were incurred for the purposes of the permanent establishment (OECD, 2010, p. 162).

However, the UN model denies a deduction for head office expenses where those expenses are payments for royalties, fees, interest, and commissions for specific management services. The UN model therefore provides for a significant expansion of the taxation of business profits earned at source. The UN model commentary acknowledges that an instance could arise whereby, if the country in which the head office of an enterprise is situated allocates to the head office some percentage of the profits of the enterprise only in respect of good management, while the country in which the permanent establishment is situated does not, the resulting total of the amounts charged to tax in the two countries would be greater than it should be (UN, 2012, p. 157). In such a case, the UN model commentary recommends that the country in which the head office of the enterprise is situated should take the initiative in arranging for such adjustments to be made in computing the taxation liability in that country as may be necessary to ensure that any double taxation is eliminated.

Article 7(3) of the Canada/RSA tax treaty contains no such expansion and is therefore based on the OECD model. This accords with Canada's treatment of middle-income countries, although Canada is quite willing to grant the UN model expansion to low-income countries; over 50 percent of Canada's tax treaties with low-income countries contain this expansion, as opposed to only four with middle-income countries and one with a high-income country (Brooks, 2009, p. 10).

\section{The Taxation on the Alienation of Property}

The taxation of capital gains among OECD member countries (and non-OECD member countries for that matter) varies considerably. In some OECD member countries, capital gains are taxed as ordinary income and therefore added to the income from other sources. This applies especially to the capital gains made by the alienation of assets of an enterprise. In a number of OECD member countries, however, capital gains are subjected to special taxes, such as taxes on profits from the alienation of immovable property, or general capital gains taxes, or taxes on capital appreciation (increment taxes). Such taxes are levied on each capital gain or on the sum of the capital gains accrued during a year, mostly at special rates, which do not take into account the other income (or losses) of the taxpayer (OECD, 2010, p. 238). The OECD model does not deal with these varying tax treatments. Instead, it is left to the domestic law of each Contracting State to decide whether capital gains should be taxed and, if they are taxable, how they are to be taxed.

Article 13(1) of the OECD model states that gains from the alienation of immovable property may be taxed in the State in which it is situated. ${ }^{16}$ It applies also to immovable property forming part of the assets of an enterprise. Article 6 defines 'immovable property' so as to have the meaning it has under the law of the Contracting State in

\footnotetext{
${ }^{15}$ The OECD model commentary considers it appropriate, in the case of general administrative expenses incurred at the head office of the enterprise, to take into account a proportionate part based on the ratio that the permanent establishment's turnover (or perhaps gross profit) bears to that of the enterprise as a whole. Subject to this, it is considered that the amount of expenses to be taken into account as incurred for the purposes of the permanent establishment should be the actual amount so incurred. The deduction allowable to the permanent establishment for any of the expenses of the enterprise attributed to it does not depend upon the actual reimbursement of such expenses by the permanent establishment.

${ }^{16}$ This rule corresponds to the provisions of Art 6 and of Art 22(1).
} 
which the property in question is situated. ${ }^{17}$ It should be noted that Art 13(1) deals only with gains which a resident of a Contracting State derives from the alienation of immovable property situated in the other Contracting State. According to the OECD model commentary, the paragraph does not apply to gains derived from the alienation of immovable property situated in the Contracting State of which the alienator is a resident (OECD, 2010, p. 242). The UN model contains the same wording.

Article 13(2) of the OECD model deals with movable property forming part of the business property of a permanent establishment of an enterprise. The term 'movable property' means all property other than immovable property which is dealt with in Art 13(1) (OECD, 2010, p. 242). Movable property also includes incorporeal property, such as goodwill, licences, etc. Gains from the alienation of such assets may be taxed in the State in which the permanent establishment is situated. The UN model extends source taxation by also applying Art 13(2) rules when movable property of a permanent establishment (or fixed base) is alienated, as well as when the permanent establishment as such - alone or with the whole enterprise (or the fixed base as such) - is alienated (UN, 2012, p. 232). ${ }^{18}$

The OECD model provides broad protections for source-based taxation of income (but not alienation) from real property, presumably on the basis that such property has a strong economic connection to the source state (Brooks, 2009, p. 11). Therefore, the source state does not need to demonstrate that the taxpayer has a permanent establishment in order to tax income from immovable property.

As regards to the alienation of immovable property, Art 13(1) of the Canada/RSA tax treaty echoes the wording of both the OECD and UN models. As regards to the alienation of movable property, Art 13(2) of the Canada/RSA tax treaty follows the wording prescribed in the UN model. In other words, Canada feels strongly enough about the ability to tax income from the alienation of movable property in Canada that it has been willing to include expanded source taxation on this basis in its treaties, regardless of the income status of its negotiating partner; in all but eight of the 56 tax treaties negotiated between 1988 and December 2012 the ability to tax nonresidents on the disposition of property is preserved (Brooks, 2009, p. 11).

\section{CONCLUSION}

This paper has reviewed the concept of permanent establishment in the context of a double tax agreement between a developed country (Canada) and a developing country (South Africa). The OECD model (2010, p. 10) deals with the elimination of double taxation, but also addresses the prevention of tax evasion and nondiscrimination. The elimination of double taxation is achieved (in part) by effectively reducing the tax base of the source country (usually the low-income country) and thus increasing the tax earnings of the residence country (usually the high-income country) (Avi-Yonah, 2007). This is done in two ways (Brooks, 2009, p. 2):

- $\quad$ Reduce the scope for the source taxation of business income through the definition of a permanent establishment as a requirement for source taxation; and

- $\quad$ Reduce the withholding tax rate on passive income earned in the source country.

Consequently, the extent to which a country's tax treaty policy favours developing countries or not depends upon the extent to which the country is prepared to adopt provisions from the UN model (i.e., those articles that enhance the scope for the source taxation of business income) as opposed to the OECD model. When negotiating with developing countries, many developed countries are prepared to adopt some provisions from the UN model; this provides some indication of their concern that developing countries be able to retain their tax base in crossborder transactions (Brooks, 2009, p. 2).

\footnotetext{
${ }^{17}$ Per Art 6(2) of the OECD model, immovable property includes property accessory to immovable property, livestock, and equipment used in agriculture and forestry, rights to which the provisions of general law respecting landed property apply, usufruct of immovable property and rights to variable or fixed payments as consideration for the working of, or the right to work, mineral deposits, sources, and other natural resources; ships, boats, and aircraft shall not be regarded as immovable property.

${ }^{18}$ The UN model commentary notes that par 2 is not based on the 'force of attraction' principle. The paragraph merely provides that gains from the alienation of movable property forming part of the business property of a permanent establishment (or of movable property pertaining to a fixed base used for performing independent personal services) may be taxed in the state where the permanent establishment (or the fixed base) is situated.
} 
The Canada/RSA treaty is overwhelmingly based on the OECD model. It could therefore be argued that, notwithstanding that developing countries advanced the UN model so as to retain greater source taxation (UN, 2012, p. vii), South Africa seems to have a deliberate tax treaty policy to cede taxing rights to other countries. ${ }^{19}$ Granted, this policy is probably aimed at encouraging foreign investment, especially by capital-exporting developed countries. But at what cost to the developing country's fiscus? Moreover, this reliance on the OECD model could perhaps imply that developing countries are unable or unwilling to make use of the UN model so as to retain greater source taxation.

The following attributes, as contained in the Canada/RSA treaty, are in accordance with the OECD model:

- $\quad$ A period of activity of more than twelve months is required for a building site or construction or assembly project to exist to be considered a permanent establishment.

- The list of preparatory or ancillary activities which are excluded from being considered a permanent establishment.

- If a dependent agent is able to habitually exercise the authority to conclude contracts in the name of the enterprise, the agent will constitute a permanent establishment.

- $\quad$ No provision is made for considering an independent agent to be a permanent establishment where their activities are wholly or almost wholly devoted to the enterprise.

- $\quad$ No inclusion is made to recognise insurance activities as a permanent establishment.

- $\quad$ The basis on which profit is allocated to entities with a permanent establishment, namely

- No limited force of attraction rule is provided for and

- Head office expenses may be deducted in calculating the profits of a permanent establishment.

Only one attribute incorporates wording contained in the UN model, namely the taxation on the alienation of movable property. Another attribute follows neither the OECD model nor the UN model, viz. the general furnishing of services is required to continue for a period of more than twelve months.

Pursuant to a general policy shift towards incorporating more UN model (instead of OECD model) provisions,$^{20}$ the following, briefly, are recommendations as to how the scope for the source taxation of business income in the developing country (specifically South Africa) could be magnified through treaty negotiations: ${ }^{21}$

a) Lower the threshold for taxation of business profits

This proposal relates to the threshold of activity required before a non-resident would be subject to tax in a lower-income country on its business activities in that country. Based on the UN model provisions, the following changes would have to be negotiated:

- The period of activity for a building site, etc. to be considered a permanent establishment must be lowered from twelve to six months.

- $\quad$ Ancillary services should be regarded as a permanent establishment if the activities continued for more than 183 days in a twelve-month period.

- $\quad$ The delivery of goods should not be in the list of services excluded from being a permanent establishment.

- The concept of dependent agent should be extended to an agent who either concludes contracts on behalf of the developing country or (if he/she has no authority) who regularly delivers goods or merchandise on behalf of the enterprise.

\footnotetext{
${ }^{19}$ Moreover, the fact that the Canada/RSA treaty is predominantly based on the OECD model, could ostensibly be an indicator of Canada's relative lack of concern with the protection of South Africa's tax base.

${ }^{20}$ Of course, it is debatable whether a developing country would be in a position to exert much influence over its tax treaty design when negotiating with a developed country.

${ }^{21}$ These recommendations could form the starting point of future research, wherein the effect (or at least the potential effect) of a change in provisions could be measured. Of course, the researcher would require access to comprehensive and reliable tax statistics. In all likelihood, a colloborative research effort - spanning economics, law, taxation, and accounting - might be required.
} 
- $\quad$ An independent agent should be considered a permanent establishment where their activities are wholly or almost wholly devoted to the enterprise.

- Insurance activities should be regarded as a permanent establishment.

b) Expand the scope of what profit should be allocated to an enterprise

This recommendation would include a limited force of attraction rule, whereby all income derived by the enterprise in the developing country jurisdiction, should be subject to tax there. Furthermore, by limiting the amount of head office expenses to be deducted in the calculation of the business income of the permanent establishment, its net profit (and resulting taxable income) will increase, thereby increasing tax revenue.

c) Allow the taxation of technical or management fees with minimal connection to the source state

When a taxpayer lacks a permanent establishment, the business income is not subject to tax in the source country (in other words, South Africa). If, however, the developing country were able to negotiate a technical or management fees article that allows it to impose a withholding tax on such fees, tax revenue could consequently be generated, despite the absence of a permanent establishment. ${ }^{22}$

d) Permit the taxation of gains on the alienation of real property

This proposal refers to the ability of the source country (namely South Africa) to tax the permanent establishment on the alienation of property. It could be suggested that this capacity to tax the resulting capital gains - in respect of both immovable and movable property - be preserved in the treaty.

In conclusion, foreign direct investment is a driver of economic growth and countries that adopt policies to facilitate this investment while simultaneously protecting national sovereignty, are likely to achieve greater economic well-being than those that do not (Barthel, Busse, Krever, \& Neumayer, 2010, p. 17). Developing countries in particular should carefully consider the design of their tax treaty policy so as to effectively combat tax avoidance, without sacrificing foreign direct investment.

\section{AUTHOR INFORMATION}

Lee-Ann Steenkamp, University of the Western Cape, South Africa. E-mail: lee-ann@outlook.com

\section{REFERENCES}

1. Avi-Yonah, R. S. (2001). Globalization and tax competition: Implications for developing countries. Cepal Review, 74, 59-66.

2. Avi-Yonah, R. S. (2007). International tax as international law: an analysis of the international tax regime. Cambridge University Press.

3. Barthel, F., Busse, M., Krever, R., \& Neumayer, E. (2010). The relationship between double taxation treaties and foreign direct investment. Tax Treaties: Views From The Bridge-Building Bridges Between Law And Economics, 3-18.

4. Brooks, K. (2009). Canada's evolving tax treaty policy toward low-income countries. Retrieved 14 March 2012from http://papers.ssrn.com/sol3/papers.cfm?abstract_id=1352647

5. Duff, D. G. (2010). Responses to tax treaty shopping: A comparative evaluation. Retrieved 3 April 2012 from http://papers.ssrn.com/sol3/papers.cfm?abstract_id=1688689

6. Elliffe, C. (2011). International tax avoidance - The tension between protecting the tax base and certainty of law. Journal of Business Law, 7.

7. Haupt, P. (2012). Notes on South African income tax. Roggebaai: H\&H Publications.

8. Martín Jiménez, A. J. (2004). The 2003 revision of the OECD commentaries on the improper use of tax treaties: A case for the declining effect of the OECD commentaries? Bulletin - Tax Treaty Monitor. IBFD Publications.

\footnotetext{
${ }^{22}$ Brooks (2009, p. 11) observes that Canada has, in a few cases, permitted the inclusion of such a withholding tax provision.
} 
9. Mazansky, E. (2009). South Africa's treaty network - Why is South Africa the meat in the sandwich? Bulletin - Tax Treaty Monitor. IBFD Publications.

10. Neumayer, E. (2007). Do double taxation treaties increase foreign direct investment to developing countries? Journal of Development Studies, 43(8), 1501-1519.

11. Oguttu, A. W. (2006). Transfer pricing and tax avoidance: Is the arm's-length principle still relevant in the e-commerce era? SA Merc LJ, 18, 138-158.

12. Oguttu, A. W. (2009). The challenges of taxing profits attributed to permanent establishments: A South African perspective. SA Merc LJ, 21, 773-803.

13. Organisation for Economic Cooperation and Development (OECD). (2010). Model tax convention on income and on capital. Retrieved 8 Oct. 2012 from http://www.oecd-ilibrary.org/taxation/model-taxconvention-on-income-and-on-capital-2010_9789264175181-en

14. Organisation for Economic Cooperation and Development (OECD). (2011). OECD's current tax agenda. Retrieved 7 Nov. 2012 from http://www.oecd.org/site/ctpfta/

15. South Africa. (1997). Convention between the republic of South Africa and Canada for the avoidance of double taxation and the prevention of fiscal evasion with respect to taxes on income. Pretoria: Government Printer.

16. South Africa. (2014). The Income Tax Act, Act 58 of 1962. Pretoria: Government Printer.

17. South African Revenue Service (SARS). (2002). Interpretation Note No.6: Place of effective management (persons other than natural persons). Pretoria: Government Printer.

18. South African Revenue Service (SARS). (2011). Discussion paper on interpretation Note 6 place of effective management. Pretoria: Government Printer.

19. Steenkamp, L.-A. (2013). Beneficial ownership provisions in tax treaties between developed and developing countries: the Canada/South Africa example. International Business and Economics Research Journal, 12(9), 1107-1118.

20. United Nations (UN) Department of Economic and Social Affairs (DESA). 2012. United Nations model double taxation convention between developed and developing countries. Retrieved 26 Oct. 2012 from http://www.un.org/en/development/desa/publications/double-taxation-convention.html

21. Vann, R. (2011). The UN model and agent: "Wholly or almost wholly". (Sydney Law School Legal Studies Research Paper No. 11/62). Retrieved 14 May 2012 from http://ssrn.com/abstract=1935712

22. West, C. (2009). The taxation of international (non-resident) sportspersons in South Africa: A critical analysis of the relevance of the OECD model Article 17 in double tax agreements from a South African perspective and the misalignment of this article in South African DTAs (in Force at 1 June 2008) when compared against the final withholding tax on the gross earnings of non-resident sportspersons performing in South Africa (Doctoral dissertation). University of Cape Town. 
NOTES 